\title{
Determinants of Ethiopia's Coffee Bilateral Trade Flows: A panel Gravity Approach
}

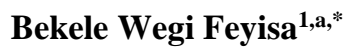 \\ ${ }^{1}$ School of Agricultural Economics and Agribusiness, Haramaya University, Ethiopia \\ *Corresponding author
}

A R T I C L I N F O A B S T R A T

Research Article

Ethiopia's export earning is heavily dependent on primary agricultural commodities and raw materials. Coffee has been the principal export commodity of Ethiopia for many years and continued to be the leading export commodity. The objective of this paper was, therefore, to identify the determinants of Ethiopia's coffee export to the major trading partners. Eighteen countries were

Received : 26/03/2020

Accepted : 14/12/2020 selected based on the importance of the country as Ethiopia's coffee export destination and availability of the required data. Annual panel data from 2001 to 2016 was collected from FAO database and other relevant sources. After appropriate econometric tests had been applied, random effect model was selected and used to analyze the data. From the seven variables entered into the model, four variables were found to affect Ethiopia's coffee export significantly. GDP of the importing countries and population size of Ethiopia affect Ethiopia's coffee export positively as

Keywords: Bilateral Trade

Coffee

Export expected. Weighted distance between Ethiopia and its trading partners was also found to have an expected effect, negative, on Ethiopia's coffee export. Contrary to the hypothesis, foreign direct investment flows to Ethiopia affected Ethiopia's coffee export negatively. Based on the results, the study draws conclusion and policy implications. To increase Ethiopia's coffee export, government and other stakeholders should give prime attention to countries where there is high demand for Ethiopia's coffee. Moreover, coffee exporters should exploit the existing nearest market opportunities. Finally, favourable conditions should be created for the large unemployed labor of the country to increase coffee production and export.

bekeleewegi@gmail.com

(iD)https://orcid.org/0000-0002-3917-7095|

(c) (1) () This work is licensed under Creative Commons Attribution 4.0 International License

\section{Introduction}

International trade has been argued to significantly increase the welfare of trading partners since the classical economists had tried to explain the gains from international trade. Different economists have forwarded the reasons for international trade and its importance for economic growth and development from different perspectives. Smith (1776) in his publication "wealthy of nations" argue that nations specialize in the commodity of their absolute advantage and export to other nations in exchange for other commodities. He added that this enable nations to allocate labor to where labor is more efficient and increase world output.

Economic development is one of the prime objectives of all countries in general and developing countries in particular. Economic growth has been argued to be the fundamental and engine for economic development. Although the level and rate of economic development depend primarily on internal conditions in developing nations, most economists believe that international trade can contribute significantly to the development process (Dominidik, 2011).
With about 105 million people, Ethiopia is the second most populous nation in Africa after Nigeria, and the fastest growing economy in the region. The country's economy has been growing by two digit over the last five years. This is by far greater than the average regional growth of $5.4 \%$ (World Bank, 2018). However, it is also one of the poorest, with a per capita income of \$783. Like other developing countries, Ethiopia's economy relies on the success of agriculture sector which is dominated by subsistence farmers. Export earnings of the country is also heavily dependent on primary commodities, especially agricultural commodities and raw materials.

Coffee is one of the most important commodities and widely consumed beverages all over the world. It is one of the most valuable primary products in world trade, in many years second in value next to oil as a source of foreign exchange for producing countries (Lewin et al., 2004). It has the largest sales volume and the longest history among fair trade products (Cerjak et al., 2015). It is also crucial to the economies and policies, accounting for more than $50 \%$ of world's least developed countries exports (ICO, 2015). 
In 2014 , the global production was about 9 billion tons. The two most important species of coffee are Arabica coffee, which accounts for about $55 \%$ of world production, and Robusta coffee (USDA, 2014).

Ethiopia is the birthplace of coffee Arabica and coffee is vital to the economic, social and traditional life of the people of Ethiopia. Millions of people of Ethiopia are dependent on coffee sector and participate in coffee sector in farming, picking and transporting (Meskela and Teshome, 2014). Coffee has been the principal export commodity for Ethiopia for many years and continued to be the leading export commodity. Over the last four years, coffee accounts for about $37.25 \%$ of the total agricultural export earnings and $31 \%$ of the total export earnings of the country. During the 2017/18 marketing year alone, Ethiopia had earned about 917 million US dollars from coffee exports (GAIN, 2019).

However, export basket of the country is limited to few commodities such as coffee, oilseeds, pulses, and leather products. This coupled with increasing expenditure on import of manufactured commodity has contributed for continuous trade deficit Ethiopia has been facing (Yeshineh, 2016). The figure 1 shows how much Ethiopian merchandise trade deficit has been increased over time. In 2000, the merchandise trade deficit was about 774 million USD. It has been increased and reached 13864 million USD in 2017.

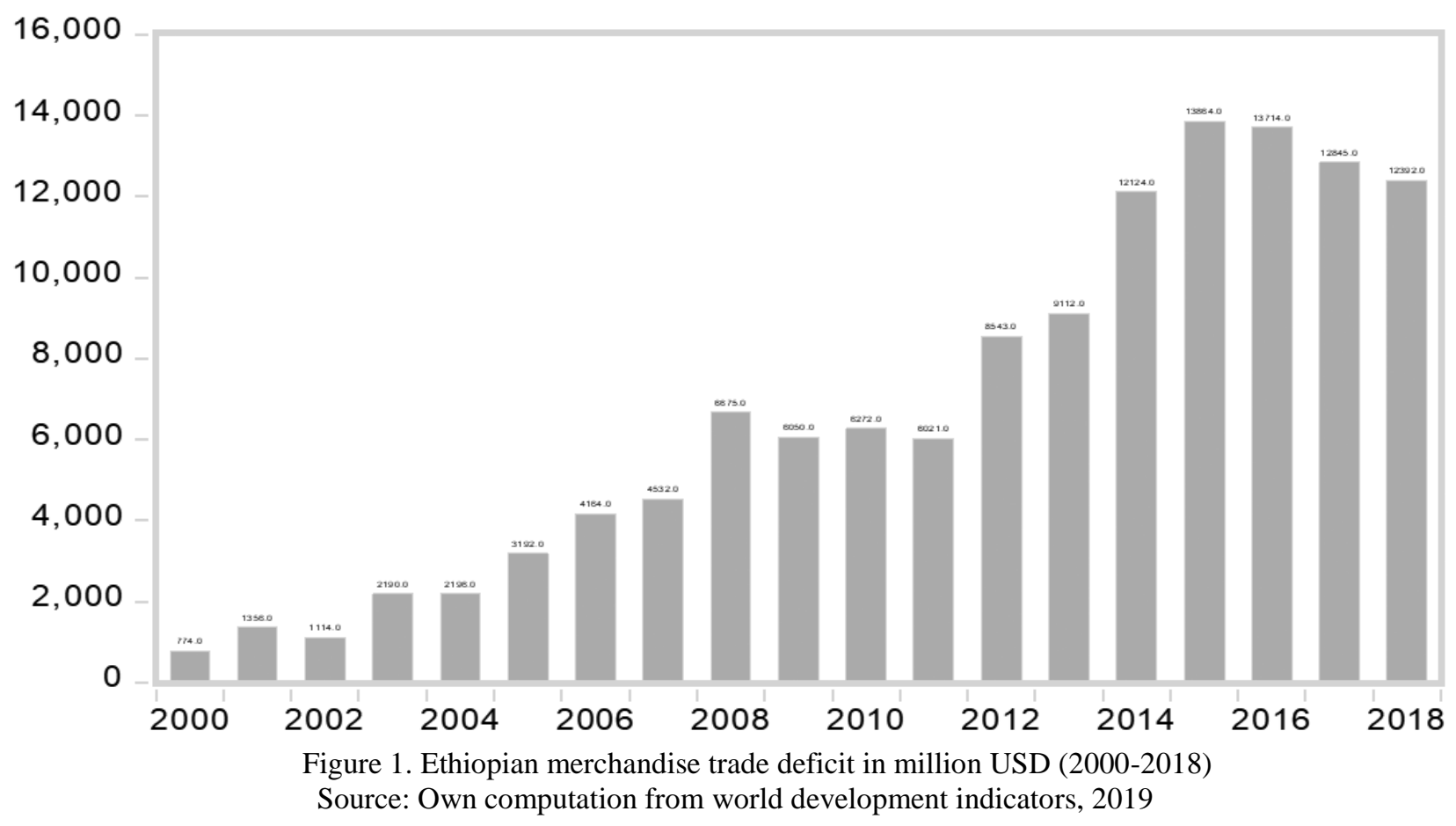

According to World Development Indicators (2019), Ethiopia's GDP has been growing impressively. In addition to this, the population of Ethiopia has also been growing rapidly. These lead to increased demand for foreign goods. As a result, Ethiopian merchandise import is by far greater than Ethiopian merchandise export. As indicated on figure, Ethiopia had never financed its merchandise import from merchandise export over the last nineteen years.

Given the significant contribution of coffee to export earnings of the country, it is crucial to identify the determinants of coffee export flows at least to minimize trade deficit by focusing on key variables affecting coffee export flows. Therefore, this study aimed to identify the determinants of Ethiopia's coffee bilateral trade flows with its major trading partners.

This paper analyzed Ethiopia's coffee export to its trading partners (eighteen coffee importing countries). It used a panel data collected from different sources on different variables from 2001 to 2016. It also employed annual data for each variables. The paper is limited to only one commodity (coffee) and determinants of coffee export. This was done due to the fact that coffee is the primary export commodity of Ethiopia and Ethiopia had not imported significant amount of green coffee during the study period from the mentioned countries. Therefore, bilateral trade flows and Ethiopia's coffee export are interchangeably used in this paper.

The remainder of this paper is organized as follows: Theoretical framework of international trade flow is reviewed and presented in section two. Section three presents the research methodology employed to prepare this paper. It includes types and sources of data, econometric model specifications, selections and definitions of variables. The main findings of the paper is discussed in section four. Finally, concluding remarks and policy implications are drawn in section five.

\section{Theoretical Frameworks}

The Gravity model has been widely used to analyses the determinants of bilateral trade flow. Its origin goes back to the Isaac Newton's "Universal Law of Gravitation" advanced in 1687. He argued that the attractive force between two objects (say $\mathrm{i}$ and $\mathrm{j}$ ) is proportional to the product of masses of the two objects and inversely related to the distance between the two objects. Accordingly, the attractive force $(F)$ between two objects $i$ and $j$ is given by: 


$$
F_{i j}=G \frac{M_{i} M_{j}}{D_{i j}^{2}}
$$

Where: $\mathrm{F}$ is attractive force between the two objects, $\mathrm{M}$ is mass of the objects, $\mathrm{D}$ is the distance between the objects and $\mathrm{G}$ is the gravitational constant.

Tinbergen (1962) proposed a similar form to explain international trade flows.

$$
F_{i j}=\beta_{o} \frac{M_{i}^{\beta 1} M_{j}^{\beta 2}}{D_{i j}^{\beta 3}}
$$

Where: $F_{i j}$ is the trade flow between country $i$ to $\mathrm{j}, \mathrm{M}$ is economic mass (usually measured in GDP), Dij is the distance between the two countries (measured in kilometer). Taking the logarithm of equation (2) gives linear form of traditional gravity model of bilateral trade flows.

$$
\ln F_{i j}=\beta_{o}+\ln \beta_{1} M_{i}+\ln \beta_{2} M_{j}+\ln \beta_{3} D_{i j}
$$

Tinbergen (1962) suggested that the capacity of one country's export supply to another country depends on its economic size and the magnitude of the importing country's market. He also noted that distance is used to specify the transportation cost for the goods between the two countries. The sign of the coefficients $\left(\beta_{1}\right.$ and $\left.\beta_{2}\right)$ are expected to be positive while sign of the coefficients of distance $\left(\beta_{3}\right)$ is expected to be negative since distance is a proxy for transportation cost. This implies that the higher the distance between the trading partners, the lower the bilateral trade flows would be.

Gravity model had been criticized for lack of theoretical foundations and has been attracted economists to put strong theoretical foundations. Many empirical studies have been conducted to validate the reliability of gravity model (see Anderson, 1979; Bergstrand, 1985; Helpman and Krugman, 1985). In recent empirical literature, other variables have been added to the traditional gravity model to reflect the factors that determine trade flows between trading partners. Additional variables can be incorporated to control for the differences in geographical factors, historical ties and sets of dummy variables either restricting or facilitating trade between countries (see, Mengistu, 2014; Zeray and Gachen, 2014; Dlamini et al., 2016; Bekele and Mersha, 2019).

\section{Research Methodology}

\section{Types and Sources of Data}

Secondary data was collected from different sources particularly FAO database and WB database. The study covered the period from 2001 to 2016. The paper used annual data for every variable included in the gravity model. Moreover, eighteen Ethiopia's coffee importing countries were identified and included. Countries were selected based on the importance of the country as Ethiopia's coffee export destination and availability of the required data. Therefore, the paper used a panel data to identify the determinants of Ethiopia's coffee export flows.

\section{Econometric Model Specification}

The paper adopted the gravity model of bilateral trade analysis. Several studies used gravity model to analyze bilateral trade flows. Recent literature expanded the gravity model to incorporate different variables believed to determine a bilateral trade flows. Anderson and Wincoop (2003) argue that the factors affect the volume of bilateral trade include the level of economic activity, income, and the barriers to trade such as transportation cost, uncertainty, cultural difference, common borders and regulatory constraints.

In this paper, various variables expected to determine Ethiopia's coffee export flows are added to the model following previous empirical studies (Kassa, 2013; Mengistu, 2014; Zeray and Gachen, 2014; Bekele and Mersha, 2019). Accordingly, in addition to the traditional gravity model's variables (GDP and distance between trading partners), Population size of Ethiopia and that of trading partners, real exchange rate between Ethiopia and Ethiopia's coffee importing countries and foreign direct investment flow to Ethiopia were included into the model. The model used in this paper is specified as follow:

$$
\begin{aligned}
& \ln C_{i j t}=\beta_{0}+\beta_{1} \ln \mathrm{GDP}_{\mathrm{it}}+\beta_{2} \ln \mathrm{GDP}_{\mathrm{Jt}}+\beta_{3} \ln \mathrm{WDST}_{\mathrm{ij}}+ \\
& \beta_{4} \ln \mathrm{P}_{\mathrm{it}}+\beta_{5} \ln \mathrm{P}_{\mathrm{jt}}+\beta_{6} \ln \mathrm{RER}_{\mathrm{ijt}}+\beta_{7} \ln \mathrm{FDI}_{\mathrm{it}}+\varepsilon_{\mathrm{ijt}}
\end{aligned}
$$

\section{Where:}

$i$ is coffee exporting country (Ethiopia)

$\mathrm{j}$ is Ethiopia's coffee importing countries $(\mathrm{j}=1,2,3, \ldots, 18)$

$C_{i j t}$ is the value of Ethiopia's coffee export in million USD to country $\mathrm{j}$ at time $\mathrm{t}$

$G D P_{i t}$ is the value of Ethiopia's GDP in million USD at time $\mathrm{t}$

$G D P_{j t}$ is the value of country j's GDP in million USD at time $\mathrm{t}$

$W D S T_{i j}$ is the relative (weighted) distance between Ethiopia and country $\mathrm{j}$ in $\mathrm{km}$

$P_{i t}$ is the population of Ethiopia in million at time $\mathrm{t}$

$P_{j t}$ is the population of country $\mathrm{j}$ in million at time $\mathrm{t}$

$R E R_{i j t}$ is a real exchange rate between Ethiopia and country $\mathrm{j}$ at time $\mathrm{t}$

$F D I_{i t}$ is foreign direct investment flow to Ethiopia in million USD at time $\mathrm{t}$

$\varepsilon_{i j t}$ is a uniformly and identically distributed error term

\section{Variables Definition and Hypothesis}

Dependent variable:

Annual value of coffee export $\left(C_{i j t}\right)$ : It is a dependent variable measured in million USD per year. It measures the value of Ethiopia's coffee exported to its trading partner at year $\mathrm{t}$. The data was extracted from FAO database.

Gross Domestic Product $\left(G D P_{i t}\right.$ and $\left.G D P_{j t}\right)$ : Data on GDP of Ethiopia and its coffee trading partners in million USD was extracted from FAO database. This is considered as a proxy for income of the trading partners (Ethiopia and its coffee trading partners) and expected to affect coffee bilateral trade flows positively. Previous studies found that income of Ethiopia and its trading partners measured by their GDP affected the volume of Ethiopia's coffee export flows (Mengistu, 2014; Bekele and Mersha 2019). 
Distance between Ethiopia and its trading partners (DISTij): It is a geographical distance between Ethiopia and Ethiopia's coffee importing countries. It was measured in kilometer from Addis Ababa, capital city of Ethiopia, to the capital cities of the selected countries. The data was obtained from www.distancefromto.net. Distance between Ethiopia and its coffee trading partners is a proxy for transportation cost and expected to affect Ethiopia's coffee export flows negatively. Several previous studies argue that weighted distance should be taken to avoid the time invariable nature of the absolute distance to measure the distance between trading partners in order to get intuitive computation of the model (Yishak, 2009; Nguyen, 2010; Zeray and Gachen, 2014). Following their arguments, weighted distance between Ethiopia and country $\mathrm{j}$ at time $\mathrm{t}$ (WDIST $T_{\mathrm{ijt}}$ ) was calculated as follow:

$$
\operatorname{WDIST}_{\mathrm{ijt}}=\frac{\operatorname{DIST}_{\mathrm{ij}}{ }^{*} \mathrm{GDP}_{\mathrm{it}}}{\Sigma \mathrm{GDP}_{\mathrm{it}}}
$$

DIST $_{\mathrm{ij}}$ is a geographical distance between Ethiopia and its Coffee trading partners, GDP it $_{\text {is }}$ the gross domestic product of Ethiopia at time $t$ and $\Sigma G D P_{i t}$ is the summation of GDP of Ethiopia over the entire study period.

Population $\left(P_{i t}\right.$ and $\left.P_{j t}\right)$ : It represents the total population of Ethiopia and its coffee trading partners at time $t$, respectively. This data was also extracted from FAO database. In the literature, there is a debate on the effect of population size on bilateral trade flows. For example, Gebrehiwot and Gebru (2015) argue that exporting country with higher population can either export more because of higher production capacity (economies of scale) or export less because of more consumption capacity. They pointed similar argument for importing country. Therefore, population size of Ethiopia and Ethiopia's coffee importing countries can affect Ethiopia's coffee trade flows either positively or negatively.

Foreign Direct Investment $\left(F D I E_{t}\right)$ : It is the total foreign direct investment flow to Ethiopia in million USD at time t. Rise in investment through foreign direct investments could be a potential for a country to expand export industry and, therefore, expected to affect Ethiopia's coffee export flows positively.

Real Bilateral Exchange Rate $\left(R E R_{i j t}\right)$ : It is a proxy for the relative price of foreign goods in terms of domestic goods. It measures real bilateral exchange rate between Ethiopia and its coffee trading partners at time t. It was computed using the formula.

$$
\mathrm{RBR}_{\mathrm{ijt}}=\mathrm{E} \frac{\mathrm{P}^{*}}{\mathrm{P}}
$$

Where $\mathrm{E}$ is the bilateral nominal exchange rate between Ethiopia and country $\mathrm{j}, \mathrm{P}$ is the Ethiopian consumer price index and $\mathrm{P}^{*}$ is country $\mathrm{j}^{\prime} \mathrm{s}$ consumer price index. Economic theory explain the relationship between exchange rate and foreign demand for goods. The lower the real bilateral exchange, the higher the quantity of goods demanded by foreign countries given that it requires fewer units of foreign currency to buy one unit of domestic currency (Bekele and Mersha, 2019). Therefore, real bilateral exchange rate between Ethiopia and its coffee trading partners is hypothesized to affect Ethiopia's coffee export flows negatively.

\section{Results and Discussion}

This section presents results of econometric model. The data was analyzed using STATA software. Augmented gravity model (random effect model) was employed to identify the determinants of Ethiopia's coffee export. Both the dependent variable and independent variables were converted into logarithm to make variables closer to the normal distribution.

\section{Specification Tests}

Prior to the application of random effect model, different tests had applied to check appropriateness of the model. Hausman test was applied to select a model which best fits a data set among fixed effect and random effect models. The test result revealed that probability $>\mathrm{chi}^{2}=0.6835$ (Table 3 ). This suggests failure to reject null hypothesis and random effect model fits the data well. Therefore, random effect model was chosen based on Hausman test result. The next step was checking the model that is appropriate among Pooled Ordinary Least Square (Pooled OLS) and random effect model. Breusch and Pagan Lagrangian multiplier test for random effects was applied for this purpose. The test result revealed that a null hypothesis that suggests Pooled OLS is appropriate, was rejected at $1 \%$ significance level (Table 4). Following this test result, random effect model was chosen over Pooled OLS and applied to identify the determinants of Ethiopia's coffee export to eighteen selected countries.

Determinants of Ethiopia's Coffee Bilateral Trade Flow

About seven variables expected to determine Ethiopia's coffee export were included as independent variables. Of the independent variables included in the model, four variables (GDP of importing countries, population of Ethiopia, weighted distance between Ethiopia's capital city and capital cities of importing countries and foreign direct investment flow to Ethiopia) were found to be statistically significant variables affecting Ethiopia's coffee export flows.

The model is significant at $1 \%$ significance level. The null hypothesis (all the coefficients are simultaneously zero) is rejected (Table 1). Therefore, the model best explain the determinants of Ethiopia's coffee export flows.

The independent variables significantly affecting Ethiopia's coffee export flows are briefly discussed below:

GDP of importing countries (GDPj): As hypothesized, GDP of importing countries was found to have a positive and significant effect on Ethiopia's coffee export at $1 \%$ significance level. This finding is consistent with the theory of gravity model. Furthermore, it is consistent with previous studies. For example, Dlamini et al. (2016) and Nguyen (2018) found that GDP of importing country affected Swaziland's Sugar export and Vietnam's bilateral trade flows. They argue that the higher the GDP of importing country, the higher the demand for foreign goods. The coefficient of GDP of importing countries implies that an increase in GDP of importing countries by $1 \%$ increases Ethiopia's coffee export by $1.799 \%$, keeping other variables constant. 
Table 1. Determinants of Ethiopia's Coffee Exports (Random Effect Model Result)

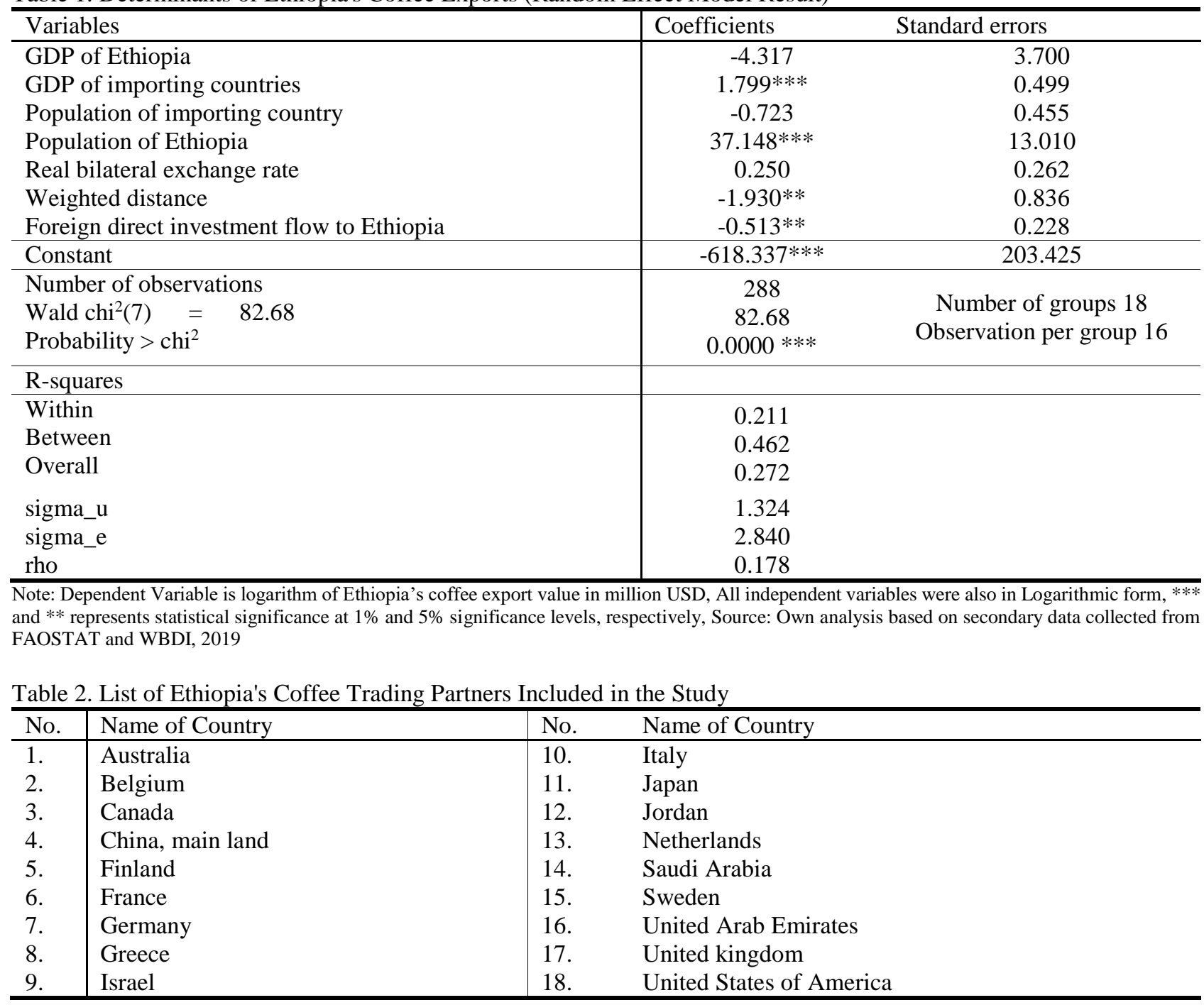

Table 3. Hausman Test Result

\begin{tabular}{l|cccc}
\hline \multirow{2}{*}{} & \multicolumn{3}{c}{ Coefficients } \\
\cline { 2 - 5 } & $\mathrm{B}$ & $\mathrm{B}$ & $\mathrm{b}-\mathrm{B}$ & sqrt(diag(V_b-V_B)) \\
\cline { 2 - 5 } LGDPE & $\mathrm{Fe}$ & $\mathrm{Re}$ & Difference & S.E \\
LGDP & -1.431732 & 1.317202 & 2.885469 & 3.069742 \\
LPJ & 1.527027 & -0.7231625 & -0.2717832 & 1.564224 \\
LPE & -2.041776 & 37.14778 & -1.318614 & -1.318614 \\
LRER & 41.82975 & 0.2497864 & 4.681976 & 7.712155 \\
LWDIST & 1.085083 & -1.935265 & 0.8352963 & 0.8687833 \\
LFDIE & -4.511549 & -0.5129977 & -2.576284 & 2.802741 \\
\end{tabular}

$\mathrm{b}=$ consistent under Ho and Ha; obtained from xtreg, $\mathrm{B}=$ inconsistent under Ha, efficient under Ho; obtained from xtreg, Test: Ho: difference in coefficients not systematic, $\operatorname{chi}^{2}(7)=(\mathrm{b}-\mathrm{B})^{\prime}\left[\left(\mathrm{V}_{-} \mathrm{b}-\mathrm{V} \_\mathrm{B}\right)^{\wedge}(-1)\right](\mathrm{b}-\mathrm{B}),=4.81,{\text { Prob }>\mathrm{chi}^{2}}^{2}=0.6835$

Table 4. Breusch and Pagan Lagrangian multiplier test for random effects

\begin{tabular}{l|cc}
\hline \multicolumn{1}{c|}{ Variables } & Coefficients & Standard errors \\
\hline LEXPV & -4.317 & 3.700 \\
E & $1.799^{* * *}$ & 0.499 \\
U & -0.723 & 0.455 \\
Test: $\operatorname{Var}(\mathrm{u})=0$ & & \\
chibar $(01)$ & 33.26 & \\
${\text { Probability }>\text { chibar }^{2}}^{\text {PEXPV }}$ \\
\hline
\end{tabular}

LEXPV represents the logarithm of coffee export value in million USD price 
Population of Ethiopia (POPE): The second variable that has statistically significant effect on Ethiopia's coffee export is population size of the country. The coefficient of population of Ethiopia shows a significant and positive effect on Ethiopia's coffee export at 1\% significance level. As can be seen from its coefficient, as Ethiopia's population increases by $1 \%$, Ethiopia's coffee export will rise by $37.148 \%$, keeping other factors constant. This could be because of the country's abundant labor of which majority of its labor force is employed in agriculture sector. This finding is consistent with the classical theories and Heckscher-Ohlin theory of trade. Previous empirical studies had also witnessed that an increase in exporting country's population encouraged export of that country. Bekele and Mersha (2019) used a dynamic panel gravity model using annual panel data to analyze Ethiopia's coffee export performance. They found that Ethiopia's population has a positive relation with Ethiopia's coffee export performance.

Weighted distance between Ethiopia and its Coffee importing countries: As expected, this variable has turned out to have a significant and negative relation with Ethiopia's coffee export at 5\% significance level. This is consistent with the theory of gravity model and international trade theories. Previous empirical studies also found that distance between trading partners has a negative relation with bilateral trade flows. For instance, Zeray and Gachen (2014) analyzed the determinants of Ethiopia's bilateral trade flows and found that distance between trading partners has a negative effects on bilateral trade flows. They argue that distance is a proxy for transportation cost which hamper international trade. The coefficient of the variable shows that, keeping other factors constant, $1 \%$ increase in the relative distance between Ethiopia and its coffee importing countries will decrease coffee export (trade flow) by $1.93 \%$.

Foreign direct investment flow to Ethiopia (FDIE): Contrary to the hypothesis, the variable has turned out to have a negative and significant relation with Ethiopia's coffee export at 5\% significance level. Its coefficient indicates that as foreign direct investment flow to Ethiopia increases by $1 \%$, Ethiopia's coffee export will decrease by $0.513 \%$, keeping other variables constant. Similar to this finding, Oparanya et al. (2019) analyzed bilateral trade flows in east African community using gravity model. His finding suggests that foreign direct investment flow negatively affects bilateral trade flows. The possible reason for Ethiopia's case could be export diversion effect of the foreign direct investment flow to Ethiopia. Ethiopia has been exporting agricultural commodities and coffee has been the first commodity as a source of foreign currency earnings. However, since recent years, the government of Ethiopia has put effort to invest in other sectors to minimize trade deficits the county has been facing. This could divert resources from investment in coffee to other sectors of the economy and might have negatively affected Ethiopia's coffee export flows. The data used in this study is annual data of foreign direct investment flow to Ethiopia. Therefore, increase in foreign direct investment flow does not necessarily increase the production and export of coffee.

\section{Conclusion and Policy Implications}

\section{Conclusion}

International trade has been argued to be an engine for economic growth and development. Especially, international agricultural trade is continued to be the major export commodity for the majority of developing countries. The contribution of coffee export for least developing countries' foreign earning is indispensable. Ethiopia, known to be the birthplace of coffee Arabica, heavily depends on coffee export for foreign currency earnings.

This paper aimed to explore the determinants of Ethiopia's coffee export to eighteen selected countries. In achieving this objective, annual panel data from 2001 to 2016 was collected from different sources. The paper employed augmented gravity model of bilateral trade analysis to identify the determinants of Ethiopia's coffee export. Before applying random effect model, different tests were undertaken to select a model which best fits the data among Pooled OLS, random effect and fixed effect models. Accordingly, Random effect model was found to be appropriate and applied to identify the determinants of Ethiopia's coffee export.

From the seven variables entered into random effect model, four variables were found to have statistically significant effect on Ethiopia's coffee export to the selected countries. As a result, GDP of importing countries and population size of Ethiopia indicated significant and positive relation with Ethiopia's coffee export at $1 \%$ significance level. The other two variables, weighted distance between capital of Ethiopia and capital of importing countries and foreign direct investment flow to Ethiopia showed negative and statistically significant relation with Ethiopia's coffee export at 5\% significance level. The negative relation between foreign direct investment and Ethiopia's coffee export was not expected. It could be justified since recent years; the government of Ethiopia has put effort to invest in other sectors to minimize trade deficits the county has been facing. This could divert resources from investment in coffee to other sectors of the economy and could have negatively affected Ethiopia's coffee export flows.

\section{Policy Implications}

Based on the findings of the study, particularly, random effect model output, the following policy implications have been drawn.

Results of the model showed that GDP of importing countries have positive relationship with Ethiopia's coffee export. This implies that the higher the economies of the importing countries, the higher the demand for Ethiopia's coffee and Ethiopia export more coffee. Therefore, the government of Ethiopia and coffee exporters should give prime consideration to countries where demand for coffee is high.

The second variable found to have a positive relation with Ethiopia's coffee export was population size of Ethiopia. As coffee production requires intensive use of labor and the country has yet high unemployment rate, it is recommended that the government and other stakeholders should pave a ways to incorporate labor to enhance coffee production and export. 
Another important variable found to determine Ethiopia's coffee export was relative distance between Ethiopia and its trading partners. The variable showed a significant and negative relation with Ethiopia's coffee export. This indicates that transportation cost hamper coffee export. Therefore, coffee exporters should exploit the nearest markets. They should give prime emphasis to the nearest market opportunities.

\section{Notes}

GAIN stands for Global Agricultural Information Network; ICO stands for International Coffee Organization; USDA stands for United States Department of Agriculture

\section{Funding}

The authors received no funds for this paper.

\section{Conflict of interest}

The author declared no conflict of interest.

\section{Ethical approval}

Not applicable.

\section{References}

Anderson JE. 1979. A theoretical foundation for the gravity equation. American Economic Review, 69: 106-116.

Anderson JE, Van Wincoop E. 2003. Gravity with gravitas: A solution to the border puzzle. American economic review, 93(1): 170-192.

Bekele WT, Mersha FG. 2019. A Dynamic Panel Gravity Model Application on the Determinant Factors of Ethiopia's Coffee Export Performance. Annals of Data Science, 6(4): 787-806.

Bergstrand JH. 1985. The gravity equation in international trade: some microeconomic foundations and empirical evidence. The review of economics and statistics, 474-481.

Cerjak M, Naglić T, Mesić Ž, Tomić M. 2015. Croatian consumers' knowledge and attitudes towards Fair Trade (No. 713-2016-48602).

Dlamini SG, Edriss AK, Phiri AR, Masuku MB. 2016. Determinants of Swaziland's sugar export: a gravity model approach. International Journal of Economics and Finance, 8(10): 71-81.

Dominidik S. 2011. International Economics, 11th edition John Willy \& Sons, New York.

GAIN. 2019. Global Agricultural Information Network, Coffee Annual Report, USDA Foreign Agricultural Service.
Gebrehiwot G, Gebru B. 2015. Ethiopia's foreign trade potential: inferences from a dynamic gravity approach. International Journal of Economics and Business Research, 9(4): 355-375.

Helpman E, Krugman PR. 1985. Market structure and foreign trade: Increasing returns, imperfect competition, and the international economy. MIT press.

ICO. 2015. International Coffee Organization, Coffee consumption. http://www.ico.org/new_historical.asp?section $=$ Statistics

Kassa AA. 2013. Evaluation of Ethiopia's Bilateral and Potential Exports in the Middle East: A Gravity Model Approach. Journal of Emerging Trends in Educational Research and Policy Studies, 4(1): 198.

Lewin B, Giovannucci D, Varangis P. 2004. Coffee markets: new paradigms in global supply and demand. World Bank Agriculture and Rural Development Discussion Paper, (3).

Mengistu AA. 2014. Ethiopia's export performance with major trade partners: A gravity model approach. Journal of Natural Sciences Research, 4(20): 21-28.

Meskela T, Teshome Y. 2014. From Economic Vulnerability to Sustainable Livelihoods: The Case of Oromia Coffee Farmers Cooperative Union in Ethiopia. Available at SSRN 2400132.

Nguyen BX. 2010. The determinants of Vietnamese export flows: Static and dynamic panel gravity approaches. International Journal of Economics and Finance, 2(4): 122-129.

Nguyen Q. 2018. Determinants of Vietnam's exports: An application of the gravity model. Journal of Asian Business and Economic Studies, volume 25, Special Issue 01: 103-116.

Oparanya AW, Mdadila KP, Rutasitara LK. 2019. The Determinant of Bilateral Trade in the East African Community: Application of the Gravity Model. International Journal of Economics and Finance, 11(4): 1-15.

Smith A. 1776. An inquiry into the nature and causes of the wealth of nations: Volume One. London: printed for W. Strahan; and T. Cadell, 1776.

Tinbergen J. 1962. Shaping the world economy; suggestions for an international economic policy.

USDA. 2014. United States Department of Agriculture, Coffee: World Markets and Trade. Foreign Agricultural Service/USDA Office of Global Analysis. https://apps.fas.usda.gov/psdonline/circulars/coffee.pdf.

World Bank. 2018. World Development Indicators Database, The World Bank, Washington, DC.

World Development Indicators. (2019). https://datacatalog.worldbank.org/ dataset/world-development-indicators

Yeshineh AK. 2016. Determinants and Potential of Foreign Trade in Ethiopia: A Gravity Model Analysis. Available at SSRN 2854183.

Yishak T. 2009. Determinants of Ethiopia's export performance: A gravity model analysis. Trade and development discussion paper, (01).

Zeray N, Gachen D. 2014. Determinants of Bilateral Trade between Ethiopia and Its Major Trading Partners': A Gravity Model Approach. Journal of Economics and Sustainable Development, 5, 15. 